ポリビニルアルコール系繊維に対するスチレンのグラフト重合

$$
\begin{array}{ll}
\text { 大日本紡頪株式会社川上博・森卓 } \\
\\
\end{array}
$$

\title{
GRAFT COPOLYMERIZATION OF STYRENE TO POLYVINYL ALCOHOL FIBERS
}

By Hiroshi Kawakami, Noboru Mori, Kenji Kawashima and Shigenobu Iura,

(Sakoshi Factory, Dainippon Spinning Co. Ltd (Sakoshi, Ako, Hyogo Prefecture, Japan)

Graft copolymerization of styrene to polyvinyl alcohol (PVA) films was attempted using potassium persulfate and $\alpha, \alpha^{\prime}$ azo-bis-isobutyronitrile as initiator. In the presence of water, up to $700 \%$ styrene were grafted to films, whereas in the absence of water, no styrene was grafted. Furthermore, styrene was grafted to PVA fibers swelled with water at room temperature. Fibers obtained showed good resistance to hot-water, excellent elastic recovery at low elongation, and good heatsetting property.

(Received October 14, 1960)

\section{1. 緒言}

ホリビニルアルコール（以下 PVA と略記）の皮膜あ

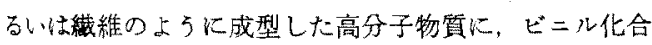
物などをグラフト重合させることは，品質改善とい5工 業的な目的から重要な意味があるばかりでなく，グラフ 卜重合の機構中重合体の構造を考える上からも與味のあ ることである。

従来 PVA に詨するグラフト重合は王としてて線に よる方法がとられている。この場合，重合系中に水を添 加するか、，PVAを索るつて水で膨潤処理した後グラ フト重合を行なうと，著しくグラフト率が上年すること が知られている1。るれわれはビニロンの弾性，熱固定 性あるいは酎熱水性などを向上させる目的でて線を使用 しないで通常のラジカル重合触媒でるる過硫酸カリ（K

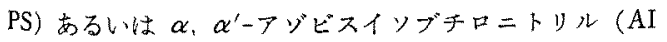
BN) を開始凪として, PVA 皮膜あるいは PVA 繊維に 対するスチレンのグラフト重合を試みだ。

まずPVA 皮膜について乐添加の影響を検討したをこ ろこれらの開始剂によるグラフト重合に括いて它水が 存在すると顕漖なグラフト率の向上が認かられた。この ような事実を参考にして PVA 瀻維に対するステレンの グラフト重合を行ない，得られたグラフト瀻維の諸性質 について検討したので，その結果を以下に報告する。

\section{PVA 皮膜に対するグラフト重合}

\section{2-1試料および実験方法}

i. 試 料

スチレン；市販品を $50 \mathrm{~mm} \mathrm{Hg}$ 下で減压蒸留し沸点 $65^{\circ} \mathrm{C}$ の留分を重合に使用した。

PVA 皮膜; 重合度 1460 , 残存酰酸基 $0.05 千 ル \%$ 市販 PVA 者 $10 \%$ 水溶液とし, 皮膜の厚さが $0.1 \mathrm{~mm}$ になるように水銀上に浮べたガラス板上に流し室温で風 乾後，ガシス板から㔀離しデシケータ中で乾學した。こ の皮膜を $1 \mathrm{~cm} \times 3 \mathrm{~cm}$ の寸法に切断して用いた。

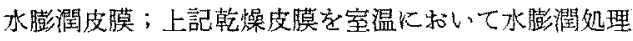
を行なつたもので膨潤度は次式で表わした。なお水膨潤 処理中に PVA 皮膜は約 $15^{\circ} \mathrm{C}$ の水江対し $5.6 \%$ の溶 解度を示したので，処理前の皮膜重量に対して補正を行 な⿰七。

膨潤度 $=(B-0.944 \mathrm{~A}) / 0.944 \mathrm{~A}$
A : 睬潤前の乾燥皮膜重量
B : 膨潤後の皮膜重量

ii. 電合方法

重合用試験管に皮膜，開始剤，モノマ一をたはモノ、 一溶液を加空気共存下で溶封し $60^{\circ} \mathrm{C}$ 恒温槽中で重合 克行なつだ

iii. 重合率の测定

重合の停止恃重合系を多量のメタノール中心投入し， 生成したポリマーを沈㔀させることによつて行なつた。 沈侮を湆別乾燥後科量し次式により重合率を算出した。 重合深 $(\%)=(\mathrm{P}-0.944 \mathrm{~A}) \times 100 / \mathrm{M}$

$$
\mathrm{P} \text { : 沈践重䁷 } \mathrm{M} \text { : 使用モノマ一熏量 }
$$

iv. グラフト率, グラフト效率の測定 


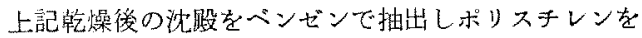
分離した。分離操作は堂温で $24 \sim 30 \mathrm{hr}$ 行ない，この間 ベンゼンは数回取換えだ。こよらな操作後の残留ポリ マーをグラフトポりマーと見なし，次式によりグラフト 條, グラフト效率を算出した。

$$
\begin{gathered}
\text { グラフト率 }(\%)=\frac{(\mathrm{G}-0.944 \mathrm{~A})}{0.944 \mathrm{~A}} \times 100 \\
\text { ブラフト効率 }(\%)=\frac{(\mathrm{G}-0.944 \mathrm{~A})}{(\mathrm{P}-0.944 \mathrm{~A})} \times 100 \\
\mathrm{G}: \text { ベンゼン抽出後のポリマー重量 }
\end{gathered}
$$

\section{2-2実験結果ならびに考察}

i. PVA 乾燥皮膜に対するグラフト重合

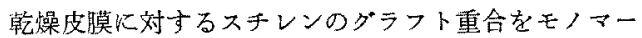
単独の場合，溶剂としてアセトンを用いた缹合，さらに 系中に水を添加した場合などについて行なつた。重合条 件怙よび結果を第1表に示す。

\begin{tabular}{|c|c|c|c|c|c|c|}
\hline \multicolumn{2}{|c|}{ 開始用( $\mathrm{g}$ ) } & 皮膜 $(\mathrm{g})$ & $\begin{array}{l}x \neq v \\
\nu(g)\end{array}$ & $\begin{array}{l}P \text { t } \\
>(g)\end{array}$ & $\begin{array}{c}\text { 水 } \\
(\mathrm{cc})\end{array}$ & 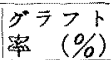 \\
\hline \multirow{3}{*}{$\begin{array}{l}\mathrm{K} \\
\mathrm{P} \\
\mathrm{S}\end{array}$} & 0.015 & 0.0393 & 3.9 & - & - & -3.6 \\
\hline & "I & 3 & 5.1 & 3.0 & - & 2.9 \\
\hline & $"$ & 0.0476 & 4.8 & 2.4 & 0.5 & 195.0 \\
\hline & & & & 3.0 & - & 6.4 \\
\hline $\mathrm{BN}$ & $"$ & 0.0395 & 3.9 & - & - & -3.3 \\
\hline
\end{tabular}

第 1 表 葫燥皮膜に奶するスチレンのグラフト重合 (重合㯰度； $60^{\circ} \mathrm{C}$ ，重合㭙間； $30 \mathrm{hr}$ )

第 1 表によれば系中に水が存在しない場合にはグラフ 卜重合は梳とんど進行しないが，氷が存在すれば乾燥皮 膜を用いてもグラフト率はかなり大きくなることがわか る。

ii. 水膨潤皮膜に詨するグラフト重合

PVA 㛺燥皮膜を水で膨潤させたbのについて，iと 同様にグラフト重合を行なつた。第 2 表にその結果を示 के.

第 2 表 水膨潤皮膜に対するスチレンのグラフト䨋合 (直合温度； $60^{\circ} \mathrm{C}$, 重合時間； $30 \mathrm{hr}$ )

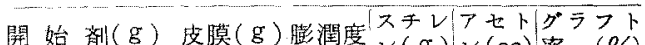

\begin{tabular}{c|c|c|c|c|c|c} 
& & \\
KPS & 0.015 & 0.0498 & 1.9 & 5.0 & - & 690 \\
& $\prime \prime$ & 0.0540 & 1.9 & 5.4 & 2.7 & 193 \\
\hline AIBN & 0.015 & 0.0437 & 2.0 & 4.4 & 2.2 & 114 \\
\hline
\end{tabular}

上表の結果から水䘗潤皮膜に対してはグラフト重合が 容易比抗こことが楒められる。第1表と考えあるせて 我の存在がグラフト重合に重要な役割をはたしているこ とは明らかである。このようと水が大きくダラフト重合 に関与寸る理由は桜由，成田，久語2 らが遮べているよ

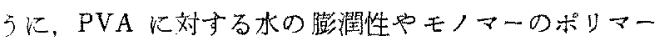

相と溶淮相における分配などが考えられる。

iii.グラフト重合におよばす種々の重合条件の影愁 以上の奏駿結果から，重合系中に水を㳢加するか，ま たは水澎潤皮膜を用いるとグラフト率が著しく增加する ことがかかつた。したがつて以下の実験では水膨潤皮膜 を用い，重合澴度仙 $60^{\circ} \mathrm{C}$ に一定として，グラフト率， グラフト就率、重合率に対するモノマー濃管，開始剂濃

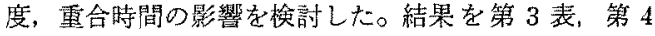
表，第 5 表乱よび第 1 図，第 2 図，第 3 図に示す。

\begin{tabular}{|c|c|c|c|c|c|c|c|}
\hline $\begin{array}{l}\text { 佊膜 } \\
(\%)\end{array}$ & 膨潤度 & $\begin{array}{l}x f v \\
(\%)\end{array}$ & {$\left[\begin{array}{l}7+1 \\
2 \%)\end{array}\right]$} & $\begin{array}{r}\text { AIBN } \\
(\%)\end{array}$ & $\begin{array}{r}\text { 重合容 } \\
(\%) \\
\end{array}$ & $\begin{array}{c}y^{-} \\
1 \\
(\%) \\
(\%)\end{array}$ & $\begin{array}{l}\text { 効率 } \\
(\%) \\
\end{array}$ \\
\hline 1.0 & 2.0 & 96.5 & - & 0.5 & 100 & 413.0 & 3.95 \\
\hline$" \prime$ & 1.9 & 85.0 & 11.5 & $" 1$ & 99.0 & 256.2 & 2.86 \\
\hline "I & 1.9 & 70.0 & 26.5 & $"$ & 69.6 & 184.3 & 3.56 \\
\hline$"$ & 1.8 & 55.0 & 41.5 & $"$ & 58.3 & 26.3 & 0.78 \\
\hline " & 1.9 & 40.0 & 56.5 & "' & 53.0 & 5. 1 & 0.21 \\
\hline
\end{tabular}

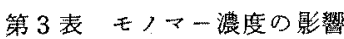

(重合湓度； $60^{\circ} \mathrm{C}$ ，重合時間；24 hr)

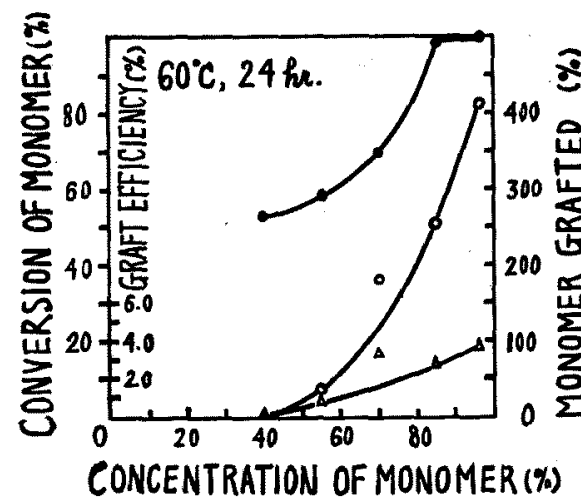

Fig. 1. Conversion of monomer, graft efficiency and grafted $\%$ vs. monomer concentration.

- conversion of monomer

-O- grafted $\%$

$-\Delta$-graft efficiency

籍 4 表 開始剤濃度に上る影響

\begin{tabular}{|c|c|c|c|c|c|c|c|}
\hline $\begin{array}{l}\text { 皮膜 } \\
(\%)\end{array}$ & 膨潤度 & \begin{tabular}{|}
$x \neq v$ \\
$(\%)$
\end{tabular} \mid & $\begin{array}{r}7+1 \\
(\%)\end{array}$ & $\begin{array}{r}\text { AIBN } \\
(\%)\end{array}$ & $\begin{array}{r}\text { 重合第 } \\
(\%)\end{array}$ & $\begin{array}{l}\not ゚ ラ 习 \\
1 \% \\
(\%)\end{array}$ & $\begin{array}{r}\text { 効率 } \\
(\%) \\
\end{array}$ \\
\hline 1.0 & 2.0 & 70 & 26.8 & 0.2 & 26.0 & 60.1 & 2.97 \\
\hline "l & 2.0 & $"$ & 26.5 & $0.5^{\prime}$ & 37.2 & 81.0 & 2.83 \\
\hline "l & 1.9 & " & 26.0 & 1.0 & 47.3 & 110.3 & 3.14 \\
\hline$" \prime$ & 1.9 & "n & 25.5 & 1.5 & 54: 2 & 98.7 & 2.39 \\
\hline " & 1.9 & $"$ & 25.0 & 2.0 & $61.0^{?}$ & 107.6 & 2.32 \\
\hline
\end{tabular}

（重合温度；60 ${ }^{\circ} \mathrm{C}$ ，重合時間；9 hr) AIBN の場合 
KPS の場合

\begin{tabular}{|c|c|c|c|c|c|c|c|}
\hline $\begin{array}{l}\text { 膜 } \\
(\%)\end{array}$ & & $\begin{array}{l}z \neq \nu \bar{T} \\
(\%)^{\prime}\end{array}$ & $\begin{array}{l}t+1 \\
(\%)\end{array}$ & $\begin{array}{r}\text { KPS } \\
(\%) \\
\end{array}$ & 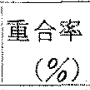 & $\begin{array}{c}3 \% \overline{7} \\
15 \\
(\%) \\
(\%)\end{array}$ & $\begin{array}{r}(\%) \\
(\%)\end{array}$ \\
\hline 1.0 & & 70 & 26.8 & 0.2 & & 90.7 & 54.4 \\
\hline " & & 11 & 26.5 & & & 186.5 & 54. \\
\hline " & & $"$ & 26.0 & & 3 & 256.0 & 55. \\
\hline & & $"$ & 25. & & & 239.2 & 9. \\
\hline & & " & 25.0 & 2.0 & 1.2 & 251.6 & 47. \\
\hline
\end{tabular}

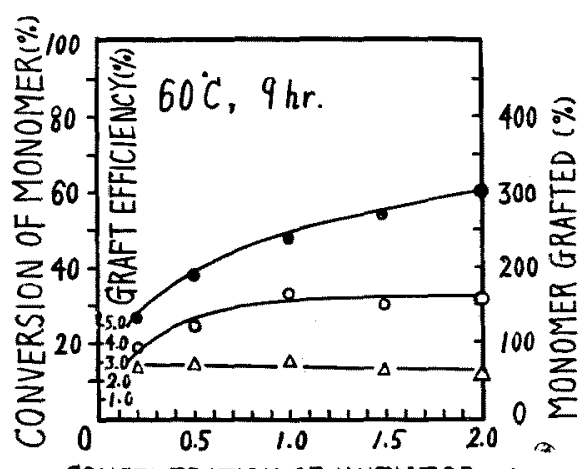

CONCENTRATION OF INITIATOR (\%)

Fig. 2-i. Conversion of monomer, grafted \% and graft efficiency $v s$. concentration of initiator.
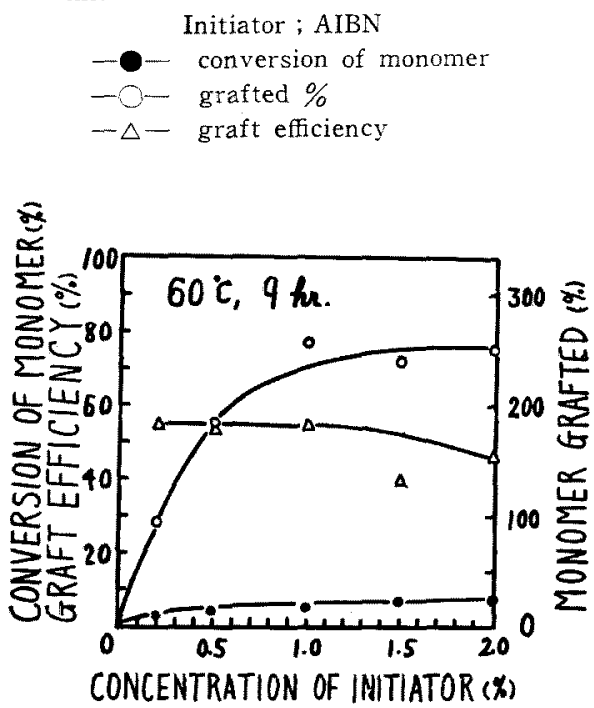

Fig. 2-ii. Conversion of monomer, grafted $\%$ and graft efficiency vs. concentration of initiator.

Initiator ; KPS

$-O-$ conversion of monomer
$-O-$ grafted $\%$
$-\triangle-$ graft efficiency

\section{第 5 表 重合時間の影韵}

(重合混度；60 $0^{\circ} \mathrm{C}$ )

\begin{tabular}{|c|c|c|c|c|c|}
\hline 需合系組成 & $\begin{array}{l}\text { 時閶 } \\
(\mathrm{hr})\end{array}$ & 噼潤度 & $\begin{array}{r}\text { 重合吅 } \\
(\%)\end{array}$ & 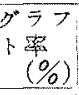 & $\begin{array}{r}\text { 效率 } \\
(\%) \\
\end{array}$ \\
\hline 膜 $(\%) ; 1.0$ & 2.0 & 1.9 & $8.6^{!}$ & 16.2 & 2.5 \\
\hline 大チレン $(\%) ; 70$ & 5.0 & 2.1 & 22.1 & 53.4 & 3.3 \\
\hline アセトン $(\%) ; 26.5$ & & 2.0 & 37.2 & 81.0 & 2.8 \\
\hline \multirow[t]{2}{*}{ AIBN } & 17.0 & 1.8 & 56.9 & 154,3 & 3.6 \\
\hline & 24.0 & 1.9 & 69.6 & 183.8 & 3.6 \\
\hline
\end{tabular}

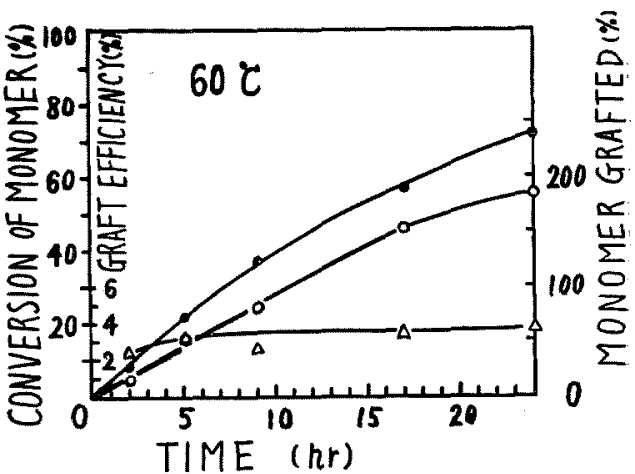

Fig. 3. Conversion of monomer, grafted $\%$ and graft efficiency vs, polymerization time.

- conversion of monomer

- O- grafted \%

$-\triangle-$ graft efficiency

第1四之第3表が明らかなよ弓に重合率，グラフト

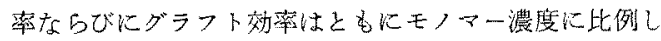
て上鼠している。

第 2 図と第 4 表から重合率は開始用謴度にともなつて 増加しているか゚，グラフト率は開始用濃度のある值まて 增加してとれ以上てい一定值となつており，したがつて グラフト効率はこの濃度以上では低下の傾向を示す。亲 た AIBN に比べて KPS のは5が重合率は小さいがダ ラフト率が大きく，グラフト效率が非常に大きいとが

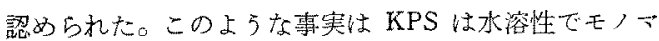
一ゃアセトンにははとんど溶けず，AIBN はこれとは适 《モクマーとアセトンの重合溶液に溶けて豖に不溶で京 るので重合の開始ならびに生長の生起する場所が両者に より相違するためと考点られる。

第3图と第 5 表を支ると重合率とグラフト率は重合时 間にともなつて上昇しているが，グラフト效率は一定時 間後は变化せず平衡状態汇遠している。

\section{PVA 繊維に対するグラフト重合}

以上の結果にもとづき，PVA 緎維に対するスチレン 
のグラフト重合を行なつて得られな瀻維について機栈的 性質，耐熱水性，熱固定性などにっいて検討した。

\section{3-1試料作铱および実験方法}

\section{i. 乾燥瀻維の製造}

重合度 1,600 のPVA 水溶液をボウ硝紡浴中で湿式 紡系し水洗乾燥した。紡系瀻維の瀻度山 $4.3 \mathrm{~d}$, 延伸率 は 264\%である。

ii. 熱延伸和よび熱処理

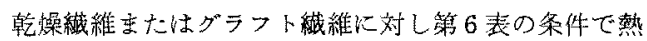
延但括よび熱処理を行なつた。

第6 表 瀻維の熱延伸拈上び熱赵理条件

\begin{tabular}{|c|c|c|c|c|c|}
\hline \multirow{2}{*}{ 記 号 } & 熱 & E 伸 & 熟 & 処 & 理 \\
\hline & $\begin{array}{c}\text { 延伸率 } \\
(\%)\end{array}$ & $\begin{array}{c}\left.\text { 温 }{ }^{\circ} \mathrm{C}\right)^{\circ} \\
\end{array}$ & $\begin{array}{l}\left.{ }^{\circ} \mathrm{C}\right) \\
\text { 度 }\end{array}$ & $\begin{array}{c}\text { 時 } \text { (間 }^{\text {(分) }} \\
\end{array}$ & 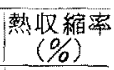 \\
\hline $\mathrm{H}-1$ & 50 & 225 & 225 & 1.0 & 5.0 \\
\hline $\mathrm{H}-2$ & 100 & " & $" 1$ & " & " \\
\hline $\mathrm{H}-3$ & 150 & $" 1$ & "I & " & $" 1$ \\
\hline $\mathrm{H}-4$ & 50 & 200 & 200 & " & $" 1$ \\
\hline
\end{tabular}

iii。ホルマール化

熱処理䋐維またはグラフト瀻維は次の条件でホルマー ル化を行なつた。硫酸；204.9 g/l, ボウ硝; $14.7 \mathrm{~g} / l$, ホルムアルデヒド； $48.9 \mathrm{~g} / \mathrm{l}$, 反応温度； $60^{\circ} \mathrm{C}$, 反応時 間； 60 分。

\section{iv. グラフト重合}

乾燥，熱処理，ホルマー化の各瀻維を水膨潤姏理した るのについて第7表の条件でグラフト重合を行なつた。 重合は皮膜の場合々同様である。すなわち執燥緎維を氷 中に漫せきして啇当に膨潤させ，次に第 7 表の GA 恃 GB の方法でグラフト重合を行ない，次いで效延伸， 熱処理しあるいはさらにホルマール化を行なつた䋐維， 乾燥瀻維をグラフト重合を行なかないで熱延伸，熱処理 後水澎洞㚭理してグラフト重合を行ない，一部はをの後 にホルマール化を行なつた瀻維,さらに熱延伸, 熱処理, ホルマール化を行なつたものについて同様に水膨䦠処理 後グラフトした絩維を製造した。試料製造の状態を図示 すると次のようである。

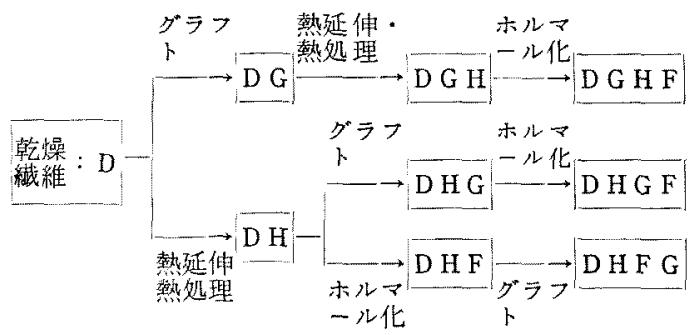

$\mathrm{G} ;$ グラフト卫程 $\mathrm{H}$; 熱正伸熱処理工程

$F$; ホルマール化工程
第 7 表 䋐維代対するグラフト重合条件

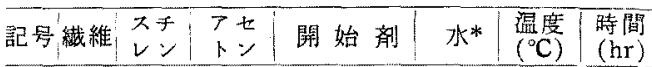
\begin{tabular}{l|l|l|l|l|l|l|l|l}
$\mathrm{GA}$ & 1 & 30 & 10 & $\mathrm{KPS}$ & 0.25 & 1.2 & 60 & 24 \\
\hline
\end{tabular}

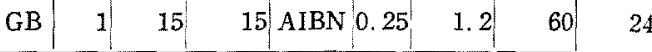

数值は箽量比を示す。

*膨潤処理により瀻維に含有された水分と系中に添加 した水の量

\section{3-2 実験結果ならびに考察}

i.グラフト率执よび繊維試験結果

第 8 表 グラフト蜜怙上び緎維試娩結果

\begin{tabular}{|c|c|c|c|c|c|}
\hline 試 料 & $\begin{array}{l}\text { ந゚ラフ } \\
\text { ト率 } \\
(\%)\end{array}$ & $(\mathrm{d})$ & 強 $\mathrm{g}$ 力 & $\begin{array}{l}\text { 強 } \text { 度 } \\
(\mathrm{d} / \mathrm{g})\end{array}$ & 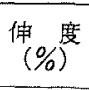 \\
\hline $\mathrm{D}$ & 0 & 5.43 & 14.39 & 2.65 & 54.9 \\
\hline $\mathrm{DH}-1$ & 0 & 3.64 & 16.86 & 4.59 & 27.6 \\
\hline $\mathrm{DH}-2$ & 0 & 2.65 & 14.47 & 6.60 & 16.7 \\
\hline DH -3 & 0 & 2. 61 & 16.11 & 6.18 & 12.1 \\
\hline $\mathrm{DH}-4$ & 0 & 3.58 & 20.43 & 5.71 & 22.2 \\
\hline $\mathrm{DG}_{\mathrm{B}}$ & 73 & 14. 35 & 18.57 & 1.29 & 181.3 \\
\hline $\mathrm{DG}_{\mathrm{B}} \mathrm{H}-1$ & 73 & 7.84 & 19.93 & 2.54 & 42.7 \\
\hline $\mathrm{DG}_{\mathrm{B}} \mathrm{H}-2$ & 73 & 6.10 & 19.88 & 3. 26 & 21.7 \\
\hline $\mathrm{DG}_{\mathrm{B}} \mathrm{H}-4$ & 73 & 6.80 & 21.10 & 3.09 & 26.1 \\
\hline $\mathrm{DH}-1-\mathrm{G}_{\mathrm{A}}$ & 219 & 10.74 & 19. 32 & 1.80 & 64.2 \\
\hline $\mathrm{DH}-2-\mathrm{G}_{\mathrm{A}}$ & 143 & 8.92 & 15.79 & 1.77 & 38.8 \\
\hline $\mathrm{DH}-3-\mathrm{G}_{\mathrm{A}}$ & 104 & 5.08 & 16.86 & 3.32 & 43.2 \\
\hline $\mathrm{DH}-4-\mathrm{G}_{\mathrm{A}}$ & 184 & 9.04 & 17.68 & & 89.3 \\
\hline $\mathrm{DH}-1-\mathrm{G}_{\mathrm{B}}$ & 28 & 5.00 & 15.74 & & 48.2 \\
\hline $\mathrm{DH}-2-\mathrm{G}_{\mathrm{B}}$ & 54 & & & & 40.4 \\
\hline $\mathrm{DH}-3-\mathrm{G}_{\mathrm{B}}$ & 11 & & & 5.69 & 16.9 \\
\hline $\mathrm{DH}-4-\mathrm{G}_{\mathrm{B}}$ & 63 & 8.23 & 20.03 & 2.43 & 75.6 \\
\hline $\mathrm{DH}-1-\mathrm{F}$ & 0 & 3.08 & 16.87 & 5.48 & 18.4 \\
\hline $\mathrm{DH}-2-\mathrm{F}$ & 0 & 4.02 & 17.04 & 4.24 & $28: 1$ \\
\hline$D H-3-F$ & 0 & 2. 48 & 16.07 & 6.48 & 15.2 \\
\hline $\mathrm{DH}-4-\mathrm{F}$ & 0 & 10.52 & 11.8 & 1.13 & 103.0 \\
\hline $\mathrm{DG}_{\mathrm{B}} \mathrm{H}-1-\mathrm{F}$ & 73 & 10.24 & 20.33 & 1.99 & 50.7 \\
\hline$D G_{B} H-2-F$ & 73 & 8.64 & 20.65 & 2.39 & 36.7 \\
\hline $\mathrm{DG}_{\mathrm{B}} \mathrm{H}-4-\mathrm{F}$ & 73 & 8.38 & 20.60 & 2.46 & 36.2 \\
\hline $\mathrm{DH}-1-\mathrm{G}_{\mathrm{A}} \mathrm{F}$ & 219 & 13.10 & 18.01 & 1. 37 & 51.4 \\
\hline $\mathrm{DH}-2-\mathrm{G}_{\mathrm{A}} \mathrm{F}$ & 143 & 5. 46 & 16.95 & 3.11 & 41. 2 \\
\hline $\mathrm{DH}-3-\mathrm{G}_{\mathrm{A}} \mathrm{F}$ & 104 & 4. 96 & 15.19 & 3.06 & 33.6 \\
\hline $\mathrm{DH}-4-\mathrm{G}_{\mathrm{A}} \mathrm{F}$ & 184 & 13.98 & 19.93 & $\therefore 1.43$ & 81.3 \\
\hline$D H-1-G_{B} F$ & 28 & 5.39 & 16.09 & 2.99 & 34.7 \\
\hline $\mathrm{DH}-2-\mathrm{G}_{\mathrm{B}} \mathrm{F}$ & 54 & 4.96 & 17,35 & 3. 50 & 33.6 \\
\hline $\mathrm{DH}-3-\mathrm{G}_{\mathrm{B}} \mathrm{F}$ & 11 & 2.76 & 14.26 & 5.17 & 16.5 \\
\hline $\mathrm{DH}-4-\mathrm{G}_{\mathrm{B}} \mathrm{F}$ & 63 & 8.21 & 18.07 & 2.20 & 55.6 \\
\hline $\mathrm{DH}-1-\mathrm{FG}_{\mathrm{A}}$ & 81 & 7.28 & 17.17 & 2. 36 & 32.7 \\
\hline $\mathrm{DH}-2-\mathrm{FG}_{\mathrm{A}}$ & 70 & 4.64 & 15.89 & 3. 43 & 25.1 \\
\hline $\mathrm{DH}-3-\mathrm{FG}_{\mathrm{A}}$ & 63 & 3.91 & 15.37 & 3.97 & 24.9 \\
\hline $\mathrm{DH}-4-\mathrm{FG}_{A}$ & 45 & 13.13 & 13.06 & 0.99 & 109.0 \\
\hline
\end{tabular}



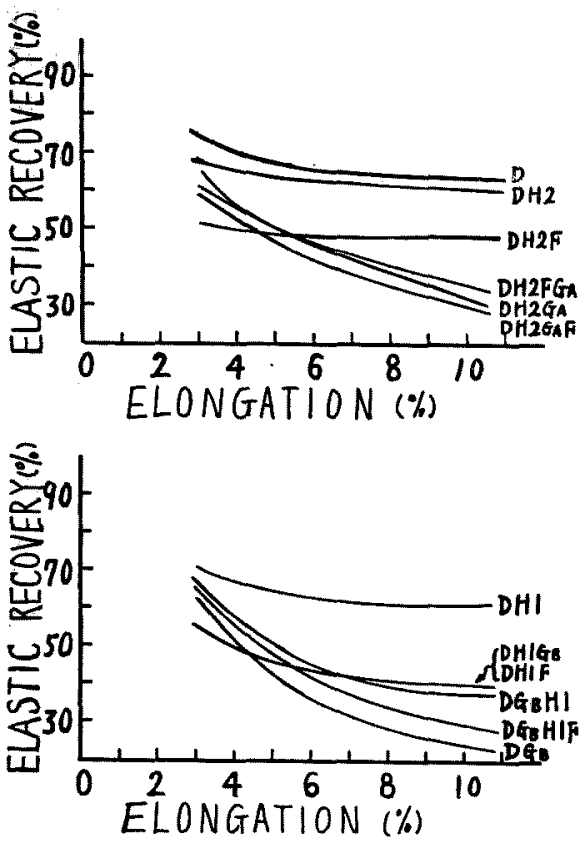

Fig. 4. Elastic recovery of grafted fiber.

グラフト率は重合条件AおよびBのいずれの場合に和 いて子乾喿瀻維>熱処理䋐維〉ホルマール化䋐維の䐓に 低下して扝り，さらに熱処理で住伸率，熱処理温度な との処理条件を強めることによりグラフト率は低下して いる。すな放結晶性，柾水性の增加ととるに低下を示 している。これらの專実からグラフト反灿は主として䋐 䊒内部の非結晶領域で起こるものと推案される。

瀻度はグラフト率により增加しており，グラフト率之 相関性が認められるが，水膨潤処理时の影響毛考虑する 必要が安る。

グラフト率による強力の変化は認められないが，グラ

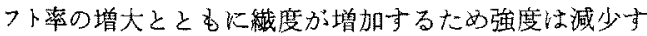
万。

伸度はグラフト率により增加する傾向を示している。 しかしグラフト率との関俰以外に水膨潤処理による繊維 の収繀の影響も岕られている。

弹性度の結果は第 4 図に㑚定結果の一部のものについ て示した。図から明らがよ5低伸長率での弹性废は 若干よいと思われるが，高伸長率においてい著しく低下 してくる。た乾燥䋐維をグラフト後熱処理した系列と 熱処理臓維をグラフトした系列とで俚そのグラフト瀻維 の棈造が異なるためなんらかの差違が弾性度に期待され るが，测定結果からはこの上5な差違は認められなかつ to ii. 耐熱水性

ボリスチレンのよ5な眯水性高分子を結合したダラフ 卜絏維は耐熱水性を向上するすのと考えられる。そこで 代表的な試料につき 1 時間沸滕水中で劣沸した場合の采 の収維率，処理㣪の状態などを調心て耐䓡水性を検討し た。結果を一括して第8表に示す。ただし収縮率は処理 乾燥後の収縮長を原系長に対する百分㭼で表わした。

第 9 表 グラフト䊺維の㴬熱水性

\begin{tabular}{|c|c|c|c|c|}
\hline 斌 & $\begin{array}{c}\text { グラフト率 } \\
(\%)\end{array}$ & 取樎率 $(\%)$ & \multicolumn{2}{|c|}{ 処理後の状態 } \\
\hline $\mathrm{DH}-1$ & 0 & - & \multicolumn{2}{|c|}{$96^{\circ} \mathrm{C}$ て溶解 } \\
\hline $\mathrm{DH}-2$ & " & - & 同 & 上 \\
\hline DH-1-F & " & 1.3 & IE & 常 \\
\hline $\mathrm{DH}-2-\mathrm{F}$ & $" 1$ & 1.8 & 同 & 上 \\
\hline $\mathrm{DG}_{\mathrm{B}}$ & 73 & 19.2 & \multicolumn{2}{|c|}{ 若干偂着 } \\
\hline $\mathrm{DG}_{\mathrm{B}} \mathrm{H}-1$ & $"$ & 22.5 & 正 & 常 \\
\hline $\mathrm{DG}_{\mathrm{B}} \mathrm{H}-2$ & $"$ & 28.0 & 闰 & 上 \\
\hline $\mathrm{DG}_{\mathrm{B}} \mathrm{H}-1-\mathrm{F}$ & $"$ & 27.3 & 同 & 上 \\
\hline $\mathrm{DG}_{\mathrm{B}} \mathrm{H}-2-\mathrm{F}$ & " & 36.9 & 同 & 上 \\
\hline $\mathrm{DH}-1-\mathrm{G}_{\mathrm{B}}$ & 28 & 49.0 & 同 & 上 \\
\hline $\mathrm{DH}-2-\mathrm{G}_{\mathrm{B}}$ & 54 & 54.3 & 同 & 上 \\
\hline DH-1- $\mathrm{G}_{\mathrm{B}} \mathrm{F}$ & 28 & 18.7 & 同 & t \\
\hline $\mathrm{DH}-2-\mathrm{G}_{\mathrm{B}} \mathrm{F}$ & 54 & 18.9 & 同 & 上 \\
\hline
\end{tabular}

第9表から明らかなように，グラフト縤維ではホルマ

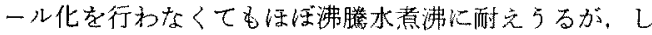
かし収樎率は若干大きい。ぬたこれらダラフト䋐維は普 通 PVA 䋐維に対するホルマール化条件ではての效果的 なホルマール化が達成されない。これはホルマール化が 主として行なわれる非結晶領域がグラフトしたポリスチ レンで扰括われていためである。

iii. 熱固定性

ポリスチレンのような熱可塑性高分子をずラフトした PVA 繊䌖は，与ぐれた熱固定性を示すである5と考完 られる。われわれは次の方法によつてグラフト戴維の熱 固定性を㛟討した9。すな⿰らがテンレスプレート（幅；

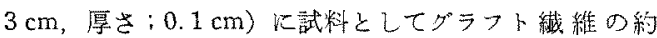
10 フィラメント莡堂什け， $100^{\circ} \mathrm{C} て 2$ 分間熱固定する。 その後 10 分間室温で放冷しプレートの一端の桪みにそ つて試料を切断する。その時の各フィライントの角度を

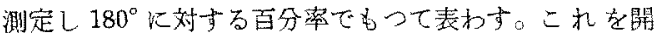
脚度としてボした。さらに比較のためた等温で同様な測 定を行なつた。またこれら熱固定したものを $60^{\circ} \mathrm{C}$ 温水 中に入れその角度の変化を調べた。な战各漬定結果は5 個の測定値の平均である。

第 10 表から明らがよ5に謺固定性はスチレンのグ ラフト率にともなつて向上する。京たグラフトした䋐就 


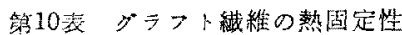

\begin{tabular}{|c|c|c|c|c|}
\hline 桻 & 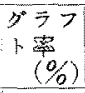 & 㪇固定条件 & 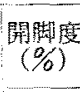 & $\begin{array}{l}60^{\circ} \mathrm{C} \text { 水 } \\
\text { での状慜 } \\
\text { 他 }\end{array}$ \\
\hline \multirow{2}{*}{$\mathrm{DH}-1$} & \multirow{2}{*}{0} & - & - & - \\
\hline & & $100^{\circ} \mathrm{C}, 2 \mathrm{~min}$ & 15.0 & $x$ \\
\hline \multirow{2}{*}{$D G_{A}$} & \multirow{2}{*}{497} & 室温, $10 \mathrm{~min}$ & 5.8 & 0 \\
\hline & & $100^{\circ} \mathrm{C}, 2 \mathrm{~min}$ & 4.1 & 0 \\
\hline \multirow{2}{*}{$\mathrm{DH}-1-\mathrm{G}_{\mathrm{A}}$} & \multirow{2}{*}{218} & 室温, $10 \mathrm{~min}$ & 9. 4 & $\bigcirc$ \\
\hline & & $100^{\circ} \mathrm{C}, 2 \mathrm{~min}$ & 4.3 & 0 \\
\hline \multirow{2}{*}{$\mathrm{DH}-2-\mathrm{G}_{\mathrm{A}}$} & \multirow{2}{*}{143} & 窒温, $10 \mathrm{~min}$ & 15.0 & $\Delta$ \\
\hline & & $100^{\circ} \mathrm{C}, 2 \mathrm{~min}$ & 13.3 & 0 \\
\hline \multirow{2}{*}{$\mathrm{DH}-3-\mathrm{G}_{\mathrm{A}}$} & \multirow{2}{*}{104} & 空温, $10 \mathrm{~min}$ & 33.0 & $\Delta$ \\
\hline & & $100^{\circ} \mathrm{C}, 2 \mathrm{~min}$ & 17.7 & $\triangle$ \\
\hline \multirow{2}{*}{$\mathrm{DH}-4-\mathrm{G}_{\mathrm{A}}$} & \multirow{2}{*}{184} & 空温, $10 \mathrm{~min}$ & 16.0 & $\triangle$ \\
\hline & & $100^{\circ} \mathrm{C}, 2 \mathrm{~min}$ & 8.3 & 0 \\
\hline
\end{tabular}

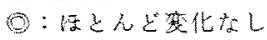

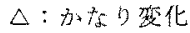

\section{O:若干変化} × : 宛全に变化

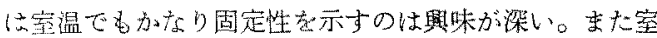

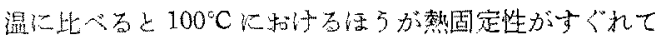

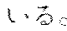

\section{9. 括}

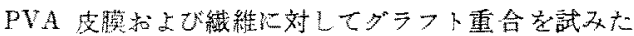
が，放射楾の場合認好られたと同様に，KPS，AIBN 放

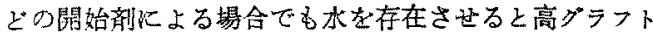
率のものが得られることを㤎めた。この場合重合系中心

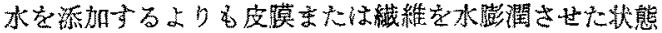
でダラフトを行なら侸らがグラフト率が大きい。グラフ

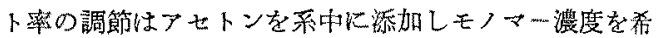
䣋することにより容弱に行ないちる。またグラフト率は

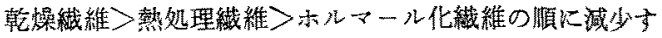
る。このよ5な事奏はグラフトが縅維の表面部分ならび に非結晶領域で起ることによるものと考えられる。

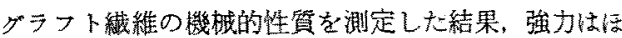
とんど变化なく，伸度は非常に增加し，弹性结低伸長率

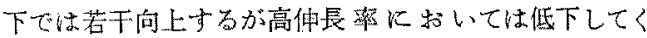

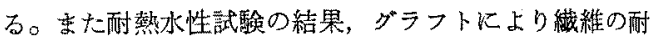
熱水性は高められ，乾燥絾維でも約 $70 \%$ 以上のグラフ

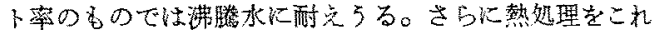
に併用守れば収維等とい5点で若干問題は残るが耐熱水 性がよ上暑方る。

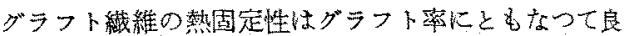
好となることを認好た。

文献

1) 桜田, 网田, 久語；Isotope and Radiation，2， $296(1959)$

2) 茹田，椆田，久語；Isotope and Radiation，2, $306(1959)$

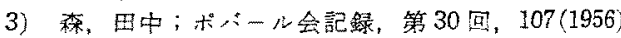

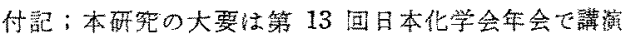
Lた。 